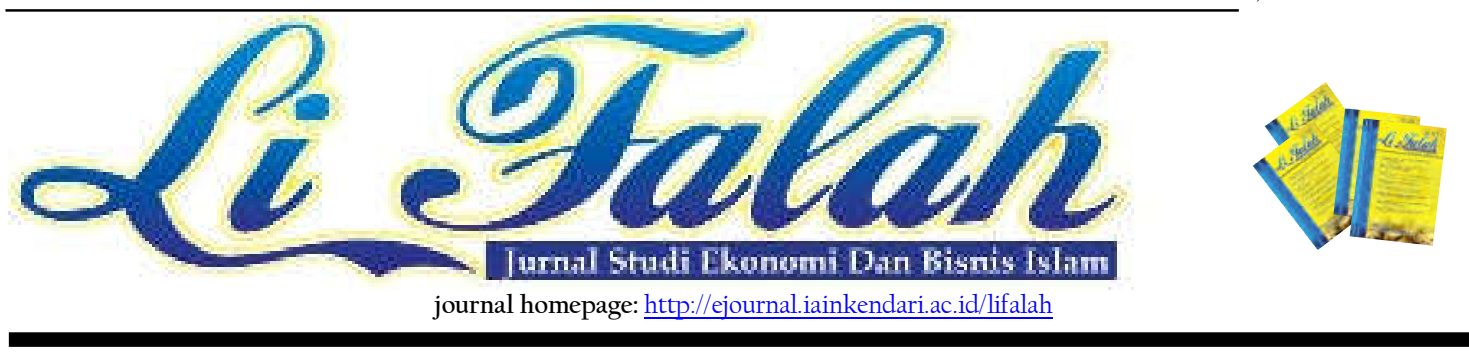

\title{
Akad Program Badan Penyelenggara Jaminan Sosial (Bpjs) Ketenagakerjaan Dalam Konteks Ekonomi Syariah
}

\section{Bahjatul Imaniyah ${ }^{1}$, Abu Hasan Agus R}

${ }^{1}$ Universitas Nurul Jadid, Probolinggo, Indonesia Email: bahjatulimaniyahl6@gmail.com

\begin{tabular}{ll}
\hline INFORMASI ARTIKEL & A B S T R A K \\
\hline \multirow{3}{*}{$\begin{array}{l}\text { Katakunci:BPJS } \\
\text { Ketenagakerjaan, }\end{array}$ Menjadi keharusan bagi semua instansi maupun individu } \\
syariah, & Bang bekerja di negara Indonesia untuk menjadi anggota \\
kesejahteraan & menjamin hidupnya saat bekerja. Tujuan penelitian ini akan \\
DOI: & kenganalisis akad program BPJS Ketenagakerjaan dalam \\
& kualitatif perspektif teoretis dengan mengumpulkan \\
dokumen dan menganalisis data baik dari segi kelas, ras dan \\
gender, tulisan ini ingin mengetahui akad yang terjadi dalam \\
BPJS Ketenagakerjaan guna menjawab beberapa \\
pertanyaan masyarakat Indonesia terkhususnya yang \\
beragama Islam (Muslim). Berdasarkan hasil pembahasan, \\
akad program BPJS Ketenagakerjaan tidak menyimpang \\
dari hukum ekonomi syariah (hukum ekonomi Islam) \\
karena, pada program Jaminan Kecelakaan Kerja (JKK) \\
termasuk akad tabarru' yang hanya dilaksanakan pada hal \\
kebajikan saja. Pada program Jaminan Kematian (JKM) \\
merupakan implementasi dari at-takmin at-ta'awuniy yaitu \\
ta'awun dalam akad tabarru'. Kedua program tersebut \\
untuk satu tujuan yaitu membantu kesejahteraan antar \\
sesama tenaga kerja. Untuk program Jaminan Hari Tua \\
(JHT), program ini memiliki konsep seperti akad \\
mudharabah musytarakah. Begitu pula dengan program \\
Jaminan Pensiun (JP) sebagai peralihan dariakadwaris.
\end{tabular}




\section{Pendahuluan}

Indonesia merupakan salah satu negara yang mayoritas penduduknya Muslim mencoba untuk hidup seperti halnya disebut dalam al-Qur'an dan Sunnah bahwasanya manusia diciptakan untuk memakmurkan bumi dengan hidup ke arah yang positif. Salah satu hal yang mengantarkan manusia ke arah positif ialah menghindari dari transaksi riba. Sebagaimana yang terjadi, dalam kehidupan pasti akan terjadi sebuah transaksi, dari sanalah kebutuhan ekonomi syariah yang sering disebut ekonomi Islam sangat dibutuhkan untuk menjalankan kegiatan sehari-hari untuk menghindari transaksi riba. Bukan hanya sebagai ilmu yang harus dikaji, ekonomi syariah juga merupakan sistem yang didasarkan pada teori dan telah diimplementasikan sejak masa Nabi Muhammad saw.,(Karim 2016:25) bahwa syari'at Islam juga membahas dan memperhatikan kehidupan manusia dalam kapasitasnya sebagai "pekerja" dan tentunya memuat prinsip-prinsip dan aturan serta konsepsi tentang "kerja" dan ajaran untuk selalu "bekerja".(Assagaf 2016:10)

Hal ini dipertegas oleh hakikat manusia sebagai khalifah di bumi yang harus melaksanakan tugasnya dengan benar dan bersungguh-sungguh untuk mendapatkan ridha Allah SWT., maka untuk memperoleh ridha tersebut, manusia harus bekerja. Syariat Islam memperhatikan kehidupan manusia sebagai pekerja yang pastinya tidak akan menyimpang dari prinsip-prinsip dan aturan yang sudah ada kapasitas dan ajarannya untuk selalu bekerja.(Anna Feberina Ginting, Salmin Diego 2016 10) Karena, pada dasarnya bekerja ialah membutuhkan tenaga dan pikiran untuk memperoleh suatu barang dan jasa.(Anna Feberina Ginting, Salmin Diego 2016: 225) Dengan bekerja, keinginan dan kebutuhan baik untuk kebutuhan diri sendiri maupun orang lain mampu dihasilkan dengan bekerja. Kehidupan sejahtera adalah kehidupan yang didambakan oleh semua manusia, tanpa memandang perbedaan agama, suku, bangsa, dan lain-lain.(Kholis 2015:224)

Dengan terpenuhinya kesejahteraan masyarakat, negara Indonesia yang merupakan negara berkembang menetapkan Badan Penyelenggara Jaminan Sosial Ketenagakerjaan yang kemudian akan disebut BPJS yang sebelum terbentuknya BPJS di Indonesia sudah ada lembaga asuransi untuk menjamin kehidupan masyarakat Indonesia sebagaimana UndangUndang Republik Indonesia Nomor 40 Tahun 2004 Tentang Sistem Jaminan Sosial Nasional Dan Undang-Undang Republik Indonesia Nomor 24 Tahun 2011 Tentang Badan Penyelenggara Jaminan Sosial. UU tersebut kemudian menggantikan sebagian jaminan sosial yang ada di Indonesia seperti, 
lembaga asuransi jaminan kesehatan yang lebih dikenal dengan PT Askes Indonesia berganti Badan Penyelenggara Jaminan Sosial (BPJS) Kesehatan dan lembaga jaminan ketenaga kerjaan berubah menjadi BPJS Ketenagakerjaan yang dipertanggungjawabkan langsung oleh Presiden Republik Indonesia kepada seluruh tenaga kerja yang mempengaruhi pembangunan nasional dan meningkatkan produktifitas nasional yang biasa disebut dengan IPM yaitu Indeks Pembangunan Manusia.(Jemikan 2018:110) Selain mempengaruhi pembangunan nasional dan meningkatkan produktifitas nasional, perlindungan yang diberikan oleh pemerintah dalam bentuk BPJS ini merupakan wujud dari peningkatan kesejahteraan dan pelayanan publik untuk kalangan masyarakat Indonesia secara adil dan merata untuk dilaksanakan.(Anggi Chrisye Piteradja, Masje Silija Pangkey 2017:1) Perlindungan tenaga kerja sebenarnya telah diatur dalam bab IV, Pasal 9 Undang-undang Nomor 14 Tahun 1969 tentang pokok-pokok tenaga kerja sebelum adanya UU BPJS. Dan sebagai lanjutan pada pasal 27 undang-undang nomor 3 tahun 1992 dan dalam undang-undang nomor 24 tahun 2011 menyebutkan bahwa pengendalian pada penyelenggara program jaminan sosial tenaga kerja dilakukan oleh BPJS di bawah Presiden.(Undang-Undang Republik Indonesia Nomor 40 Tahun 2004 Tentang
Sistem Jaminan Sosial Nasional UndangUndang Republik Indonesia Nomor 24 Tahun 2011 Tentang Badan Penyelenggara Jaminan Sosial 2011)

$$
\text { BPJS sebenarnya merupakan }
$$
tanggung jawab negara sebagaimana sabda Rasul "Saidul qaumi khadimukum" artinya, pemimpin itu ialah pelayan umat (Sula 2004:460) yang kemudian dijadikan salah satu konsep negara Indonesia yang tertuang pada rumusan Pancasila sila ke lima "keadilan sosial bagi seluruh rakyat Indonesia". Jadi, pada pasal 13 nomor 1 undang--undang nomor 40 tahun 2004 tentang Sistem Jaminan Sosial Nasional (SJSN) sebagai lanjutan dari sebuah tindakan kesejahteraan rakyat secara bertahap mewajibkan seluruh pemberi kerja untuk menjadikan pekerjanya sebagai peserta BPJS Ketenagakerjaan sesuai program yang diikuti.(Hakim 2012:11) Apabila pemberi kerja menghiraukan aturan tersebut, maka akan dikenakan sanksi sesuai Peraturan Pemerintah Nomor 86 Tahun 2013 tentang pengenaan sanksi administratif untuk instansi terkait (pemberi kerja) dan penerima kerja baik sebagai penerima upah tetap atau penerima upah tidak tetap (individu) dan penerima bantuan iuran. Peraturan mengenai BPJS adalah UU BPJS dan PP 86 Tahun 2013, aturan tersebut belum memberikan aturan yang jelas menganai penerapan sanksinya Pasal 9 PP 86 
Tahun 2013.(Permana, Suyatna, and Sarna 2017:8)

Dengan menetapkan undang-undang nomor 40 tahun 2004 tentang SJSN pada bab VI Program Jaminan Sosial nomor 1 pasal 18 tentang jenis program jaminan sosial meliputi, jaminan kecelakaan kerja, jaminan hari tua, jaminan kematian, dan jaminan kesehatan (Fatwa Dewan Syariah NasionalMajelis Ulama Indonesia 2017) sebagai program yang dibawahi langsung oleh presiden Indonesia sebagai lembaga penyelenggara jaminan sosial, BPJS Ketenagakerjaan menambahkan Jaminan Pensiun mulai 1 Juli 2015 dengan keseluruhan ada 5 program yang ada di BPJS dan khusus di BPJS Ketenagakerjaan ada 4 program selain jaminan kesehatan.(Luthfiana 2016:1661) Terlaksananya lima program jaminan sosial tersebut diharapkan bisa merata kepada seluruh tenaga kerja Indonesia secara keseluruhan baik di sektor formal maupun informal agar kebutuhan dasar serta hidup yang layak bisa terpenuhi.

Dari latar belakang di atas, ketika SJSN diratakan kepada seluruh masyarakat Indonesia tanpa memandang kelas, agama, dan suku perlu dianalisis terhadap akad program BPJS ketenagakerjaan dalam konteks ekonomi syariah.

\section{Metode Penelitian}

Tulisan ini mengggunakan metode kualitatif pendekatan perspektif teoretis dengan mengumpulkan dokumen dan menganalisis data baik dari segi kelas, ras dan gender.(Ahmadi 2016:47) Dokumen dalam hal ini bisa dari dokumen publik yaitu laporan resmi, arsip pertemuan, surat kabar, atau juga dari dokumen pribadi seperti jurnal, e-mail, surat dan catatan harian.(Creswell 2018:85) Sedangkan sumber data ialah dari yang sudah ada seperti data dari media masa, buku, laporan resmi instansi, peraturan pemerintah, peraturan presiden, peraturan mentri, peraturan dari BPJS Ketenagakerjaan, dokumen UU dan juga dari ensiklopedi dan kamus-kamus hukum.

\section{Hasil dan Pembahasan}

\section{Definisi Akad}

Dalam kesehariannya, hidup manusia tidak terpisahkan dengan kata transaksi. Karena, transaksi meruapakan kegiatan jual beli(Partanto and Barry, tt:20) yang diperlukan manusia dalam ranah ekonomi.

Perekonomian akan aman dan stabil dengan adanya suatu perjanjian (akad) sebagai dasar atau hukum. Oleh karenanya, setiap masyarakat khususnya di Indonesia yang mayoritas Muslim harus bisa memahaminya supaya bisa menertibkan suatu transaksi syariah.(ADESy 2016:169) Karena, akad adalah suatu hal penting yang 
harus ditegakkan dalam menjalankan segala kegiatan untuk meraih ridha Allah. Permasalahannya ialah persepsi antara pemerintah dan rakyat tidak selalu berjalan dalam kehidupan sehari-hari.(Kholis 2015:255) Akad dalam bahasa arab ialah "Aqd" yang berarti perjanjian atau perikatan. Secara terminologi. Sedangkan secara terminologi fiqh, akad ialah ijab qabul (ucapan serah terima) sesuai syariah yang dilakukan oleh dua orang atau lebih dengan ketentuan yang telah ditetapkan.(Haroen 2007:97)

Veithzal Rivai \& Andi Buchari mengatakan bahwa akad (perikatan, sambungan dan perjanjian) ialah pernyataan tentang perikatan yang diinginkan oleh pihak kesatu dengan pernyataan menerima dari pihak kedua yang sering disebut dengan ijab qabul tanpa menyimpang dari hukum syara'.(Rivai and Buchari 2009:344) Dapat dipahami bahwa akad adalah pernyataan serah terima suatu perikatan atau perjanjian dalam sebuah transaksi yang dilakukan oleh dua orang atau lebih tanpa menyimpang dari hukum syara'.

\section{Rukun Akad}

Rukun akad menurut jumhur Ulama fiqh ada tiga (1) Ijab qabul; (2) Para pihak yang bersangkutan; (3) Objek akad.(Haroen 2007:97) Sedangkan Mazhab Syafi'I, Maliki, dan Hambali menyatakan bahwa, rukun termasuk unsur yang membentuk akad agar sah menurut Islam. Rukun akad terdiri dari empat unsur: (1) Para pihak yang bersangkutan; (2) Ijab qabul; (3) Objek akad; (4) Tujuan akad.(ADESy 2016:174)

Berbeda lagi dengan Mazhab Hanafi yang berpegang teguh bahwa rukun akad hanya ada satu, yaitu ijab qabul. Karena, suatu rukun hanyalah esensi yang ada pada akad itu sendiri. Sedangkan para pihak yang berakad dan objek akad berada di luar esensi akad.(Haroen 2007:100) Jadi, dapat disepakati dari beberapa pendapat di atas bahwasanya dalam melaksanakan suatu akad harus terjadi ijab qabul yaitu serah terima antara pihak yang bersangkutan baik secara lisan, tulisan dan atau isyarat yang dapat dipahami supaya transaksi yang dilaksanakan sah.

\section{Syarat-Syarat Akad}

Terdapat beberapa syarat umum dalam akad yang harus dipenuhi, seperti yang telah di tetapkan ulama fiqh yaitu: (1) Mukallaf (para pihak berakad telah paham terhadap hukum syara' yang ditetapkan); (2) Objek bisa diterima hukum syara'; (3) Tidak dilarang syara; (4) Memenuhi syarat-syarat khusus yang ditetapkan pada suatu hal (transaksi) yang berbeda; (5) Tidak merugikan orang lain; (6) Terucapnya ijab qabul dengan jelas; (7) Bersatunya majlis; (8) Memiliki tujuan jelas.(Haroen 2007:101-105)

\section{Syarat Sah Akad}

Selain ada syarat-syarat dalam akad, juga terdapat syarat sahnya akad yang harus terpenuhi agar tidak membatalkan pada 
akad yaitu: (1) sesuai hukum yang telah disepakati; (2) ada unsur kerelaan (ridha); (3) harus jelas dan secara gamblang (tanpa ada yang ditutupi).(Rivai and Buchari 2009:346)

\section{Pandangan Ekonomi Syariah Terhadap} Akad Program BPJS Ketenagakerjaan

Untuk mewujudkan kesejahteraan rakyat Indonesia, negara memberikan hak untuk tenaga kerja atas jaminan sosial menyangkut risiko yang akan dialami atau pun yang telah dialami tenaga kerja dalam bekerja. Jaminan sosial ialah salah satu kebutuhan sekaligus harapan masyarakat baik yang miskin maupun yang kaya untuk untuk menanggulangi risiko yang terjadi seperti kecelekaan, kematian, pemutusan atau pemberhentian kerja dan lainnya.(Shihab 2012:177) Hal ini didasarkan pada hak-hak tenaga kerja menurut Chaudry yang dikutip oleh Sri Herianingrum dan Tika Widiastuti diantaranya ialah:(ADESy 2016:231-232)

Pertama. Tenaga kerja harus memperoleh perawatan atau biaya perawatan jika sakit pada saat itu dari pemberi kerja yang kemudian akan disempurnakan oleh pemerintah. Kedua. Pemberi kerja membuat ketentuan untuk dana pensiun bagi tenaga kerja yang lanjut usia dari kontribusi keduanya (peerja dan pemberi kerja) untuk dana bantuan. Ketiga. Untuk menstabilkan tingkat upah dalam negeri, pemberi kerja harus memberi jaminan kepada pekerja ketika sudah tidak dalam bekerja (berhenti bekerja). Keempat. Ketika terjadi kecelakaan pada pekerja dalam bekerja, pemberi kerja harus mengganti rugi kecelakaan yang cukup. Kelima. Ketersediaan akomodasi harus cukup hingga kesehatan dan efisiensi bekerja tenaga kerja maksimal.

Berdasarkan hak-hak tenaga kerja di atas, jaminan ini dilakukan oleh pemerintah untuk masa depan rakyatnya dengan cara memotong sebagian upah selama bekerja baik yang bersifat bulanan, triwulan, atau periode yang telah disesuaikan.(Karim 2013:274) Beberapa program jaminan sosial dari negara ialah berupa Jaminan Kecelakaan Kerja (JKK), Jaminan Kematian (JKM), Jaminan Hari Tua (JHT), dan juga Jaminan Pensiun (JP) yang berpayung kepada BPJS Ketenagakerjaan. BPJS Ketenagakerjan ini bergerak dalam asuransi sosial yang sebelumnya bernama PT Jamsostek (Persero) sebagaimana tercantum pada undang-undang Republik Indonesia nomor 40 tahun 2004 tentang Sistem Jaminan Sosial Nasional dan undang-undang Republik Indonesia nomor 24 tahun 2011 tentang Badan Penyelenggara Jaminan Sosial.(Peraturan Pemerintah Republik Indonesia Nomor 45 Tahun 2015 Tentang Penyelenggaraan Program Jaminan Pensiun 2015)

a.Program Jaminan Kecelakaan Kerja $(\mathrm{JKK})$ 
Risiko dalam bekerja tidak dapat Indonesia Nomor 13 Tahun 2003 tentang diantisipasi maupun diinterpretasi Ketenagakerjaan pada pasal 86 ayat (2) yang kejadiannya. Semua organisasi pasti sudah berbunyi "Upaya keselamatan dan kesehatan membentuk suatu pertahanan maupun kerja dimaksudkan untuk memberikan tindakan yang dalam hal ini, para pekerja sudah didaftarkan pada Badan Penyeleggara Jaminan Sosial (BPJS) Ketenagakerjaan pada awal mula bekerja dengan memotong sebagian gaji pekerja untuk membayar iuran sebagai jaminan atas terjadinya risiko dikemudian hari. Sebagaimana tercantum dalam Undang-Undang Republik Indonesia Nomor 40 Tahun 2004 Tentang Sistem Jaminan Sosial Nasional BAB IV Dewan Jaminan Sosial Nasional, pasal 17 nomor (2) Setiap pemberi kerja wajib memungut iuran dari pekerjanya, menambahkan iuran yang menjadi kewajibannya dan membayarkan iuran tersebut kepada Badan Penyelenggara Jaminan Sosial secara berkala dan pada nomor (3) Besarnya iuran ditetapkan untuk setiap jenis program secara berkala sesuai dengan perkembangan sosial, ekonomi dan kebutuhan dasar hidup yang layak untuk menghindari bahaya yang mungkin akan terjadi, seperti kelengkapan perlindungan, tindakan pengawasan, prosedur dan peraturan yang berlaku dalam suatu organisasi tersebut.(Yunita et al. 2016:47) Bahaya dalam bekerja bisa terjadi ketika berangkat kerja dari, pulang kerja, maupun pada saat bekerja atau penyakit yang terjadi di lingkungan bekerja. Sebagaimana tercantum dalam undang-undang Republik jaminan kepada pekerja disaat terjadi risiko/bahaya sewaktu bekerja dengan cara pengobatan dan rehabilitasi".(Himpunan Lengkap Undang-Undang Ketenagakerjaan 2013:167) Dari hal itu, program JKK ini berlaku agar peserta mendapatkan jaminan berupa santunan uang tunai atau perawatan sebagai perlindungan atas risiko yang telah dialami.(Endang Setiowati, Suharno 2017:157-167)

Besarnya iuran (premi) program JKK terbagi dari beberapa kelompok dilihat dari seberapa besarnya risiko yang akan terjadi dalam pekerjaan para peserta yang sepenuhnya ditanggung oleh pemberi kerja dari potongan upah pekerja. Jadi pekerja tidak usah membayar iuran sendiri premi yang ditangguhkan kepada BPJS Ketenagakerjaan yaitu: (1) Kelompok I : 0,24\% dari upah sebulan; (2) Kelompok II : 0,54\% dari upah sebulan; (3) Kelompok III : 0,89\% dari upah sebulan; (4) Kelompok IV : 1,27 dari upah sebulan; (5) Kelompok V : $1,74 \%$ dari upah sebulan.(Himpunan Lengkap Undang-Undang Ketenagakerjaan 2013:203)

Dasar dari program jaminan kerja ini adalah usaha saling tolong-menolong diantara semua yang terdaftar menjadi 
anggota BPJS Ketenagakerjaan untuk yang hal ini dikenal kata asuransi dalam mensejahterakan peserta lainnya.(Manan 2012:238) Karena, antar sesama pekerja di dorong untuk tetap mempertahankan budaya yang ada di Indonesia yaitu bekerjasama, saling membantu, bahumembahu kepada orang yang membutuhkan. Sebagaimana pula firman Allah dalam alQur'an al-Maidah ayat 2 yang artinya:

"Dan bertolong menolonglah kalian dalam kebaikan dan ketakwaan, dan janganlah kalian tolongmenolong dalam perbuatan dosa dan permusuhan"

Tolong-menolong dalam ayat ini ialah dalam hal kebajikan atau ketakwaan, yakni semua bentuk dan macam hal yang hanya membawa kepada kemaslahatan di dunia dan atau di akhirat bukan membawa kepada bencana meskipun dengan orang-orang yang tidak seiman.(M. Q. Shihab 2002:10)

Sudah jelas bahwa perbuatan saling tolong-menolong yang dalam Islam dikenal dengan kata ta'awun yaitu bentuk kerja sama di jalan yang halal dalam memperoleh keuntungan yang diperbolehkan syariat Islam sangat dianjurkan bahkan diharuskan untuk kehidupan manusia, seperti membantu atau meringankan kebutuhan nasib saudara kita agar tercukupi kebutuhannya dan membuatnya menjadi sejahtera.(Vandiantara 2017:119) Dalam ta'awun M. Arif Hakim menyikapi bahwa, dalam menjamin kesejahteraan masyarakat syariat Islam termasuk salah satu prisip utama bermuamalah. Karena, dalam ta'awun pihak yag lemah akan dibantu oleh pihak yang mampu untuk mendapatkan kesejahteraan hidup dengan mekanisme dana tabarru'.(Hakim 2012:240)

Ditinjau dari segi akad, sudah jelas bahwa JKK ini termasuk akad tabarru' yaitu semua bentuk akad yang berlandaskan kebaikan dalam rangka saling tolongmenolong bukan untuk tujuan komersial. Niat tabarru' ialah alternatif yang diperbolehkan dalam syara' guna menghindar dari praktik gharar. Premi (iuran) tabarru' tidak lain sebagai sumbangan yang diikhlaskan kepada peserta lain yang lebih membutuhkan.(Luthfiana 2016:245)

\section{b. Program Jaminan Kematian (JKM)}

Program jaminan kematian yang selanjutnya akan disebut JKM memberikan manfaat berupa uang tunai untuk peserta aktif yang meninggal dunia bukan karena kecelakaan kerja yang diberikan kepada ahli waris dan atau keluarga. Dana pada program JKM ini sebagai santunan bagi ahli waris untuk meringankan beban keluarga dan ahli waris dalam bentuk santunan uang tunai maupun berupa santunan biaya pemakaman. (www.bpjsketenagakerjaan.go.id)

Pemberi kerja menanggung iuran sebesar 0,3\% untuk jaminan kematian, Pernyataan 
ini sudah tercantum pada pasal 46 dalam Undang-Undang Republik Indonesia nomor 40 tahun 2004 tentang Sistem Jaminan Sosial Nasional. Besarnya iuran jaminan kematian bagi peserta penerima upah (pekerja dengan gaji tetap) ditentukan berdasarkan persentase tertentu dari upah atau penghasilan dan besarnya iuran jaminan kematian bagi peserta bukan penerima upah (pekerja tidak berpenghasilan tetap) ditentukan berdasarkan jumlah nominal tertentu dibayar oleh peserta. Ketentuan sebagaimana dimaksud diatur lebih lanjut dalam Peraturan Pemerintah dengan klaim jaminan kematian yang diberikan diantaranya:

(https://www.bpjsketenagakerjaan.go.id/pag e/Program-Jaminan-Kematian(JKM).html)

1) Santunan sekaligus sebesar Rpl6.200.000,00 (enam belas juta dua ratus ribu rupiah)

2) Santunan berkala selama 2 tahun, dengan rincian $24 \times \mathrm{Rp} 200.000,00=$ Rp4.800.000,00 (empat juta delapan ratus ribu rupiah) dibayar sekaligus

3) Biaya pemakaman sebesar Rp3.000.000,00 (tiga juta rupiah)

4) Bantuan Beasiswa untuk satu orang anak bagi peserta yang telah mencapai masa iur minimal 5 (lima) tahun sebesar Rpl2.000.000,00 (dua belas juta rupiah)

Total keseluruhan manfaat JKM yang diterima oleh pihak keluarga dan ahli waris dari peserta yang bersangkutan adalah Rp36.000.000,00 dengan dana yang sedemikian diharapkan bisa membantu keluarga dan ahli warisnya. Bukan hanya ada pada jaminan kecelakaan saja, program kematian ini juga juga implementasi dari bentuk at-takmin at-ta'awuniy yaitu ta'awun dalam akad tabarru' sebagaimana telah tercantum di dalam al-Qur'an untuk salingmelindungi.(Al-Hamzah 2004) Dalam ekonomi Islam, program JKK dan JKM termasuk jenis asuransi Takaful karena peserta tidak bermaksud mendapatkan keuntungan dari peserta lain tapi sama-sama berkeinginan untuk menutupi kekurangan yang dialami yaitu merasakan menangung musibah bersama dan membantu menghadapi bahaya bersama.(Karim 2013:273,283)

\section{c. Program Jaminan Hari Tua (JHT)}

Jaminan Hari Tua yang disingkat JHT bertujuan supaya jaminan pada masa pemutusan kerja atau berhenti kerja, memasuki usia pensiun, mengalami cacat total permanen (cacat yang menyebabkan seseorang tidak mampu untuk bekerja/beraktifitas kembali) dan/atau meninggal dunia,(Undang-Undang Republik Indonesia Nomor 40 Tahun 2004 Tentang Sistem Jaminan Sosial Nasional UndangUndang Republik Indonesia Nomor 24 Tahun 2011 Tentang Badan Penyelenggara Jaminan Sosial 2011) peserta tetap menerima 
upah berupa uang tunai dari dana yang sudah ditabung selagi masih bekerja. Hal ini terdapat dalam undang-undang Republik Indonesia nomor 40 tahun 2004 bab VI bagian keempat point dua tentang jaminan hari tua.

Program JHT ini merupakan satu kesatuan dengan JKK yang diharuskan bagi setiap peserta dengan sistem tabungan. Karena, jika pada program JKK sebagai antisipasi perawatan ketika terjadi risiko, maka pada JHT sebagai antisipasi untuk kebutuhan dana yang akan datang disaat sudah tidak bekerja lagi.(Assagaf 2016:27)

Sistem tabungan ini tidak sepenuhnya dari iuran pekerja, namun pemberi kerja juga ikut andil dan klaim yang akan diperoleh oleh pekerja kelak juga akan bertambah karena terjadinya penambahan dana dari pengembangan bagi hasil. Pembayaran iurannya yaitu: $2 \%$ dibayar oleh peserta dan $3,7 \%$ dibayar oleh pemberi kerja yang totalnya adalah 5,7\% dari upah.(Endang Setiowati, Suharno 2017:163) Pembayaran iuran program JHT ini ditanggung bersama oleh pemberi kerja dan pekerja, karena selain untuk tabungan di hari tua bagi pekerja juga sebagai penghargaan karena telah bekerja bertahun-tahun lamanya di perusahaan tempat ia bekerja.(Assagaf 2016:3) Tabungan pada program JHT ini akan tetap ada (tidak hangus) yang pada hal ini dalam ekonomi syariah dikenal dengan akad
mudharabah.(Anggi Chrisye Piteradja, Masje Silija Pangkey 2017:128)

Pengelolaan dan investasi dana dalam BPJS Ketenagakerjaan memiliki konsep yang sama dengan akad mudharabah musytarakah, yaitu antara iuran BPJS Ketenagakerjaan sebagai mudharib dan peserta sebagai shahibul mal disatukan. Begitu pula dengan pengelolaan dan penyertaan dana juga sama dengan akad mudharabah musytarakah.(Vandiantara 2017:128-129) Namun, perbedaannya BPJS Ketenagakerjaan tidak menjadikan dirinya sebagai mudharib dan dalam pembagian investasi tidak sama dengan ketentuan pada akad mudharabah musytarakah karena BPJS Ketenagakerjaan memiliki ketentuan sendiri dalam undang-undang BPJS sendiri.

\section{d. Program Jaminan Pensiun (JP)}

Hakikatnya, manusia memiliki batas kemampuan dalam segala hal. Seperti halnya dalam bekerja. Ketika umur sudah mencapai 56 tahun, badan dari pemilik jasad tidak lagi bekerja dengan kondusif dan efisien. Untuk menanggulangi poros kehidupan seperti itulah pemerintah mengadakan program jaminan pensiun yang kemudian disebut JP sebagai tabungan dana yang akan dibutuhkan untuk masa depan.

Dari asumsi di atas menunjukkan bahwa JP bertujuan untuk melindungi peserta atau ahli waris akibat kematian atau sebagainya 
yang dialami peserta. Karena, jika peserta meninggal dalam masa perjanjian, ahli waris akan memperoleh dana yang telah disetor sebelumnya oleh peserta yang kemudian juga mendapat keuntungan atas hasil investasi dari dana program JP ini.(Manan 2012:274) Jaminan pensiun juga berupa uang tunai yang diperoleh sebagai:(Undang-Undang Republik Indonesia Nomor 40 Tahun 2004 Tentang Sistem Jaminan Sosial Nasional Undang-Undang Republik Indonesia Nomor 24 Tahun 2011 Tentang Badan Penyelenggara Jaminan Sosial 2011:13-18)

1) Pensiun hari tua, diperoleh pekerja setelah masa pensiun hingga meninggal dunia

2) Pensiun cacat, diperoleh pekerja cacat total tetap karena kecelakaan atau karena penyakit sebelum mencapai usia pensiun hingga meninggal dunia

3) Pensiun janda/duda, diperoleh janda/duda ahli waris pekerja sampai menikah lagi atau meninggal dunia

4) Pensiun anak, diperoleh anak ahli waris sampai mecapai usia 23 tahun atau sampai menikah

5) Pensiun orang tua, diperoleh orang tua ahli waris peserta yang belum menikah sesuai ketentuan perundang-undangan.

Program ini bisa dikatakan peralihan dari teori waris. Dalam agama Islam, pemberian atau perpindahan kepemilikan suatu hal dari orang yang sudah meninggal kepada keluarganya atau ahli warisnya adalah akad waris. Dalam Al-Qur'an sudah dijelaskan sangat detail untuk ketentuan waris yang adil dan bijaksana seperti pada ayat QS. An-Nisa': 11-12 dan 176. Seorang sosiolog prancis Dr. Gustave Lebon menuturkan bahwa asa yang digariskan dalam Al-Qur'an sangat adil dan objektif, karena juga memberikan hak waris kepada seorang perempuan yang selama ini tidak ada dalam perundang-undangan.(ADESy 2016:391) Indonesia sebagai negara yang ingin mewadahi kesejahteraan masyarakatnya berusaha untuk memberi perlindungan terhadap para tenaga kerja dan keluarganya. JP disini berfungsi sebagai santunan kepada keluarga pekerja yang ditinggalkan untuk meringankan beban dana yang dibutuhkan untuk merawat peserta yang sudah meninggal. Selian itu, JP juga merupakan bentuk apresiasi dan motivasi untuk para tenaga kerja di seluruh tanah air Indonesia tanpa terkecuali dan tanpa membedakan ras, suku, gender, dan lain-lain.

Dari pembahasan program di atas bisa dipastikan bahwa akad dalam BPJS Ketenagakerjaan tidak menyimpang dari hukum ekonomi syariah, hal ini juga dipertegas dengan SJSN yang diselenggarakan berdasarkan pada prinsip : 1. Kegotong-royongan (saling membantu sesama peserta yang lebih membutuhkan); 2 . 
Nirlaba (Dana amanat, tidak dimaksudkan mencari laba, hasil pengembangan dan surplus anggaran akan dimanfaatkan sebesar-besarnya untuk kepentingan peserta); 3. Keterbukaan (kehati-hatian, akuntabilitas, efisiensi dan efektivitas); 4. Kehati-hatian; 5. Akuntabilitas; 6 Portabilitas (masa aktif kepesertaan berkelanjutan meskipun berpindah tempat kerja); 7. Kepesertaan bersifat wajib (untuk mencakup seluruh sektor pekerjaan yang ada di Indonesia tanpa ada perbedaan); 8. Dana amanat (dana yang dikelola dengan sangat baik dalam rangka mengoptimalkan dana tersebut hanya demi untuk kesejahteraan peserta); dan 9. Hasil pengelolaan dana jaminan sosial diperuntukkan secara keseluruhan sebagai pengembangan dana program yang kemudian akan dipergunakan sebagai kepentingan peserta (dari peserta dan yang akan kembali kepada peserta karena kepentingan peserta).(UndangUndang Republik Indonesia Nomor 40 Tahun 2004 Tentang Sistem Jaminan Sosial Nasional)

Untuk memastikan premi dari suatu instansi yang telah mendaftarkan tenaga kerjanya sebagai peserta BPJS Ketenagakerjaan tetap dibayarkan tepat waktu, maka perlu dikenakan sanksi sebagai bentuk ketegasan dalam perlindungan tenaga kerja tidaklah main-main. Namun, bagi yang kurang mampu sebagaimana tercantum dalam undang-undang Republik Indonesia nomor 40 Tahun 2004 tentang Sistem Jaminan Sosial Nasional, BAB V tentang Kepesertaan dan Iuran pada Pasal 17 nomor 4 bahwa, iuran program jaminan sosial untuk fakir miskin dan orang yang tidak mampu dibayarkan oleh pemerintah. Pada BAB VII tentang Masyarakat dan Muamalah (hubungan transaksi) nomor 13 dalam hukum menetapkan denda karena pembayaran telat menurut Al-Khaththab dari mazhab Maliki, sebagian ulama abad ini berpendapat bahwa hal itu diperbolehkan untuk ditetapkan bagi orang yang berutang dan mampu membayar, tapi mereka mengulur waktu pembayaran yang sudah dijanjikan, denda tersebut dianggap sedekah. Kemudian uang denda tersebut disedekahkan pada orang yang lebih membutuhkan.(Al-Qardhawi 2002:534)

Dalam syariat Islam asuransi hukumnya diperbolehkan atau halal. Pandangan ini dinyatakan oleh Abdul Wahab Khallaf, Muhammad Yusuf Musa, Abdurrahman Isa, Mustafa Ahmad Zarqa, dan Muhammad Nejatullah Siddiqie. Beberapa alasan pandangan ini ialah:

1) Dalam Al-Qur'an maupun Hadis tidak ada ketentuan nash tentang larangan praktik pengasuransian

2) Ada unsur rea diantara para peserta

3) Kemaslahatan dan atau keuntungan lebih besar daripada mudharatnya 
4) Asuransi atas dasar akad mudharabah yaitu bagi hasil

5) Asuransi dikategorikan koperasi

6) Dianalogikan atas dana pensiun atau taspen

Menurut Muhammad Abu Zahrah membolehkan asuransi dengan ketentuan sebagai asuransi bersifat sosial bukan komersial. Karena, dalam asuransi sosial tidak mengandung unsur-unsur yang dilarang oleh hukum syara' atau ekonomi syariah yang dilakukan hanya untuk kemaslahatan masyarakat. Berbeda dengan asuransi yang bersifat komersial yang terdapat hal-hal tidak sesuai dengan hukum syara'.(Manan 2012:253) Sama halnya dengan salah satu organisasi terbesar di Indonesia, Nahdhatul Ulama (NU) yang membolehkan hukumnya asuransi sosial pada putusan musyawarah dengan syaratasuransi sosial tersebut berdasarkan ta'awuniy. Tidak hanya asuransi sosial, NU juga memperbolehkan asuransi jiwa jika memenuhi syarat, yaitu: mengandung unsur tabungan, terdapat akad tabarru' yang hanya berlaku untuk hal kebajikan, investasi dana pada sektor yang diperbolehkan dalam hukum Islam, klaim dana bisa kapan saja setelah peserta sangat membutuhkan tanpa menunggu jatuh tempo, dan untuk pembayaran premi yang tidak cepat dilunaskan pada waktu yang telah ditentukan akan dianggap hutang yang bisa dilunasi pada pembayaran premi pada ketentuan berikutnya dan rekening akan tetap berlaku tanpa terjadi penutupan atau terjadi dana hangus.(Mubarrak 2016:116) Dari berbagai paparan di atas membuktikan bahwa, BPJS Ketenagakerjaan yang bergelut di ranah sosial tidak menyimpang dari hukum ekonomi syariah.

\section{Kesimpulan}

Dari hasil Penelitian Akad Program Badan Penyelenggara Jaminan Sosial (BPJS) Ketenagakerjaan dalam Konteks Ekonomi Syariah menghasilkan beberapa hal yang bisa menambahkan pengetahuan bagi masyarakat Indonesia khususnya yang Muslim. Terdapat beberapa point diantaranya:

1. Pada Program Jaminan Kecelakaan Kerja (JKK) terdapat akad tabarru' yaitu akad yang diperbolehkan hanya dalam hal kebajikan, termasuk perbuatan saling tolong-menolong antar peserta yang mengalami musibah atau resiko ketika hendak, sedang dan stelah bekerja.

2. Untuk program Jaminan Kematian (JKM) ialah dana yang diberikan kepada keluarga dan ahli waris pekerja sebagai peserta BPJS Ketenagakerjaan sebagai santunan baik berupa biaya pemakaman maupun berupa uang. Bukan hanya ada pada JKK saja, JKM ini juga juga implementasi dari bentuk at-takmin at- 
ta'awuniy yaitu ta'awun dalam akad tabarru'

sebagaimana telah tercantum di dalam al-Qur'an untuk saling tolong-menolong dan saling melindungi.

3. Program Jaminan Hari Tua (JHT) merupakan jaminan dan dengan sistem tabungan/investasi untuk keperluan peserta disaat sudah tidak bekerja lagi. JHT bukan hanya bisa di klaim setelah berumur tua, namun ketika pekerja sudah berhenti bekerja juga bisa mengklaim dana premi dari JHT. Program ini memiliki konsep seperti akad mudharabah musytarakah yaitu sistem tabungan tanpa ada perbedaan dalam penyatuan dana antara aset perusahaan dan peserta dalam pengelolaan dana investasi. Begitu pula dengan hasil dana yang dihasilkan dalam program ini tidak akan hangus, akan tetapi semakin bertambah karena memakai sistem bagi hasil.

4. Dalam program Jaminan Pensiun (JP) ada kesamaan dengan JHT yaitu memakai sistem tabungan/investasi untuk dana di masa depan. JP hanya bisa di klaim (dicairkan) dana preminya setelah memasuki umur pensiun yaitu 56 tahun. Bagi peserta yang sudah meninggal bisa dipindah nama kepemilikan atas nama keluarga atau ahli waris yang bersangkutan. JP bisa dikatakan adalah peralihan dari akad waris.
Dari pernyataan dan pendapat dalam pembahasan yang dikemukakan ditemukan bahwa akad dalam program Badan Penyelenggara Jaminan Sosial (BPJS) Ketenagakerjaan tidak menyimpang dari hukum syara' (hukum yang ada dalm ekonomi syariah).

\section{DAFTAR PUSTAKA}

Ahmadi, R. 2004. Metodologi penelitian kualitatif. Yogyakarta: Ar-Ruzz Media.

Al-Qardhawi, Y. 2002. Fatwa-Fatwa Kontemporer Jilid 3. Penerjemah: Abdul Hayyie al-Kattani dkk. Cet. 1. Jakarta: Gema Insani Press.

Creswell, J.W. 2018. Research Design (Pendekatan Metode Kualitatif, Kuantitatif, dan Campuran). Penerjemah: Achmad Fawaid \& Rianayati Kusmini Pancasari. Cet. 3. Ed. 3. Yogyakarta: Pustaka Pelajar. FORDEBI, \& ADESy. 2016. Ekonomi dan Bisnis Islam: Seri konsep dan aplikasi Ekonomi dan Bisnis Islam. Jakarta: Rajawali Pers.

Haroen, N. 2007. Fiqh Muamalah. Cet. 2. Jakarta: Penerbit Gaya Media Pratama.

Karim, A.A. 2016. Ekonomi Mikro Islami. Cet. 8. Ed. 5. Jakarta: Rajawali Pers. 2013. Fikih Ekonomi Islam. Penerjemah.

Abu Umar Basyir. IV. Jakarta: Darul Haq. Manan, A. 2012. Hukum Ekonomi Syariah dalam Perspektif Kewenangan Peradilan Agama. Jakarta: Kencana Prenada Group.

Partanto, P. \& Barry, D.M. 2001. Kamus Ilmiah Populer. Surabaya: Penerbit Arkola Surabaya.

Rivai, V. \& Buchari, A. 2009. Islamic Economics: Ekonomi Syariah bukan Opsi, Tetapi Solusi. Jakarta: PT Bumi Aksara.

Shihab, M.Q. 2012. Tafsir Al-Misbah: Pesan, Kesan dan Keserasian al-Qur'an. Cet. IX, Vol. 3. Jakarta: Lentera Hati.

Sula, M.S. 2004. Asuransi Syariah (Life and General): Konsep Dan Sistem Operasional. Jakarta: Gema Insani Press. 
tn. 2013. Himpunan Lengkap Undang-Undang Ketenagakerjaan. Cet. 1. Jogjakarta: Buku Biru.

Jurnal

Assagaf, Y. 2016. "Ketenagakerjaan Dalam Konsepsi Syari'at Islam." Jurnal Ilmiah AlSyir'ah, 1(3): 1-13.

Ginting, A.F. Dengo S. \& Kolondam H.F. 2016. "Implementasi Program Jaminan Sosial Ketenagakerjaan Di Kota Manado." Jurnal Administrasi Publik, 400(3): 1-10.

Hakim, M.A. 2012. "Analisis Aplikasi Akad Tabarru' Dalam Asuransi Syariah: Studi Kasus Pada AJB Bumiputera 1912 Syariah Cabang Kudus." Jurnal Muqtasid, 2(3): 231249.

Jemikan. 2018. "Kajian Yuridis Terhadap Pelaksanaan Bpjs Ketenagakerjaan Di Lingkungan Yayasan Perguruan 17 Agustus 1945 Surabaya." DiH Jurnal Ilmu Hukum, 27(14): 109-120.

Kholis, N. 2015. "Kesejahteraan Sosial Di Indonesia Perspektif Ekonomi Islam." Akademika, 2(20): 244-260.

Luthfiana, U. 2016. "Perlindungan Hukum Terhadap Pekerja/Buruh Penerima Upah Dalam Suatu Perusahaan Yang Tidak Diikutsertakan Dalam Keanggotaan Bpjs Ketenagakerjaan Ditinjau Dari UndangUndang Nomor 24 Tahun 2011 Tentang BPJS." Hukum Progresif, l(X): 1658-1670.

Mubarrak, H. 2016. "Kontroversi Asuransi Di Indonesia: Telaah Fatwa Majelis Ulama Indoneisa (MUI) Tentang Badan Penyelenggaraan Jaminan Sosial (BPJS)" Tsaqafah, 12(1): 105-130

Permana I.P.Y.I. Suyatna I.N. \& Sarna K. 2017. "Implementasi Undang-Undang Nomor 24 Tahun 2011 Tentang Badan Penyelenggara Jaminan Sosial Terkait Pendaftaran Peserta Program Jaminan Sosial Ketenagakerjaan Di Kabupaten Gianyar." Jurnal, 2(5): 1-14

Piteradja A.C. Pangkey M.S. \& Rares J.J. 2017. "Implementasi Program Jaminan Hari Tua Di Badan Penyelenggara Jaminan Sosial Ketenagakerjaan Kota
Manad." Jurnal Administrasi Publik, Vol. 91, 399-404

Puspitasari N. 201l. "Sejarah Perkembangan Asuransi Islam Serta Perbedaanya Dengan Asuransi Konvensional." Jeam, 1(10): 35-47

Setiowato, E. Suharno. \& Suparwi. 2017. "Pelaksanaan BPJS Ketenagakerjaan Bagi Karyawan Di Kota Surakarta Pada Kantor Cabang BPJS Ketenagakerjaan Kota Surakarta." Seminar Nasional Perlindungan Hukum Terhadap Tenaga Kesehatan Dan Pasien Dalam Perspektif UU No. 36 Tahun 2014, 157-167

Shihab, A.N. 2012. "Hadirnya Negara Di Tengah Rakyatnya Pasca Lahirnya Undang-Undang Nomor 24 Tahun 2011 Tentang Badan Penyelenggara Jaminan Sosial (The Presence Of The State Among People After The Declaration Of Law Number 24 Year 2011 Concerning Social Security Administeri." Jurnal Legislasi Indonesia, 2(9): 175-190

Tolala P.Y.M.C. Doda V. \& Josephus J. 2016. "Implementasi Layanan Jaminan Kecelakaan Kerja BPJS Pada Tenaga Kerja Bongkar Muat Di Pelabuhan Laut Manado." Jurnal Paradigma, 4(3): 43-54

Vandiantara S. 2017. "Tinjauan Hukum Islam Tehadap Proses Pengelolaan Dan Konsep Investasi Dana Premi BPJS Ketenagakerjaan." Jurnal Balance, l(XIV): 120-132

\section{Website}

Dewan Syariah Nasional-Majelis Ulama Indonesia, Fatwa Dewan Syariah NasionalMajelis Ulama Indonesia. 2011.

Program Jaminan Kematian. 2017. https://www.bpjsketenagakerjaan.go.id/ page/Program-Jaminan-Kematian (JKM).html

Al-Hamzah, Z. 2014. "BPJS dan Jaminan Sosial Syariah."[Diakses 17 Januari 2014] https://republika.co.id/berita/koran/new s-update/14/01/16/mzi35n-bpjs-danjaminan-sosial-syariah

Peraturan Pemerintah Republik Indonesia Nomor 45 Tahun 2015 Tentang Penyelenggaraan Program Jaminan Pensiun. 